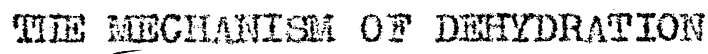

OF CALCITA SULSAPE HWHIBVDRATE

by

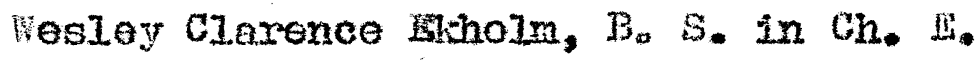

A Thesis

Presented to the Enculty of the

Pice Institute of Houstion, Teras

In Pastial FuIfilument or

the Regujactents Por the

Degreo

of

Mastor of Arts

The Rice Instibute

1936

$36-2779$ 


\section{TABL OF COMTWNS}

Introduction

Expo aimentol

a Isobaric Dohydration 8

D. X-may Diffraction Etranination 13

Di scussion

Sumaxy

BL bliograniny
20

1

23

24 
THE MECHANISO OF DEHYDRATION

OF CALCIUA SULFATE HISLTEIDRATE

The material usually designated hernihydrate of calcium sulfate thas discovered by Milion (26). Fariy investigations by Le Chatelier (24), Potilitzin (30), Iacrois (25), van't Horf (34), Davis (11), and others lod to the belfer in four separate forms of calcitm sulfate: gypsun, hemihydrato, soluble anhydrite, and anhydrite. Van't Horf and covorkers studied the vapor prossure relationships botween the various forms and reported the equilibrium temperatures with vater. Glasenapp (18), Gauderroy (16), and Grenge (19) studied the dehydration of the hemihydrate erystallographlcally bat fallod to sind any chenge in crystal form except the conversion to anhydrite. The recent series of investigations was started In 1924 by Lincle and Jung (25), who stualed the dohydretion by means of heating ourves, Isobarle and isothoxmal. dohydration, and variation in density and optical properties with composition. Their isothern indicatod a continuous loss of water throughout the entire range of dehydration. They deduced from this that the coapound vas of zeolit1c nature and interpreted their othor results to be in agreement vith this conclusion. Both density and optical properties shoved a gradual change vith loss of vater. Jung (2I) later made the first x-ray investigation of the problem and reported that the hemihydrate retains its structure on heating until traneromed 
into anhydrite at high temperatures.

Balaren (I) in 1926 clatmed that Linck and Jung did not walt for equilibrium in determining their isothorm. Ho studied the dehydration isobaricalig and concluded. that the hemihydrate decomposed stepvise, not zeolitically at $97 \pm 2^{\circ}$ and $23 \mathrm{~mm}$. aqueous vapor pressure.

Chassevent (10) checised the existence of the homihydrate by measuring electric conductivity and concentration or solutions and liboration of heat during transformation.

In 1927. throe pepers on the hemihydrate question appoared. Balarev (2) deduced from the standpoint of vant Hofr's vapor pressure vork that there must be two soluble forms of anhydrous calcium sulfate. Ho then obtained. date to indicate the existence or these two foums by means of dilatometric studies and heating curves. Parsons (28) failod to find any indication of the hemihydrate on dehydratIng gypsum and stated that it could be prepared only by Wet methods if it existed. Stumper (33) investigated the gypsum dehydration by moans of heating curves and found evidonce of the homihydrate. His results on isobaric dehydration showed no indication of hemihydrate, in agreement with Shuksulcé Kôzu and Méich Masuda (32). However, he correctly attributed the absence of a break in the curve to the short equilibritum time.

Partridge and white (29) did not $f$ ind a soluble anhydrite solid phase in their study of tho calciun sulfate- 
Fator equilibrium. Rambdell and Partridge (31) studied the dehydration by x-ray diffraction mothods and roported. that the powder photograph for dehydrated heminydrate vas Identical with that for homihydrate.

Belarev (5) in his third paper redotomined the isotherm at $96.5^{\circ}$. He concluded that the hemihydrate dehydrates neither purely hydratically nor purely zoolitically, but as a combination or these two processes. The dehydretion is hydratic in that:

(1) it procoeds fran a dorintte chemical compound

(2) the dehyriration is monovariant, the pressurecomposition curve folloning parallel to the composition aris. The process is zeolitic in that:

(1) In the region of reversible rehydration no now definite phase is formed-the optical properties chengo gradueliy

(2) the reversible dehydration camot be carried to completion. At the removal of the last bit of vater, there is a spontaneous change of properties.

Balaren also stated that there roelly exist two soluble Porms of anhydrous calciun sulfate-soluble anhydrite and dehydrated honthydrete, but admitted he was mistaken about the $\alpha$ and $\beta$ forms of soluble anhydrite previously reported.

The isotherm was reported to be purely zeolitic by Iraus and Jorns (22) in 1930, while Fill (13) in 1931 said microscopic investigations revealed thet the decomposition is hydratic. 
Gibson and Holt (17), using a differential tensimeter, obtained a pressure-temperature curvo which showed no discontinuity when hemihydrate was being converted into anhydrous salt and concluded that the water was held zeolitically.

An x-ray study of the dohydration was camied out by Feitnecht (12) using copper radiation ond a camere $57.3 \mathrm{~mm}$. In diamoter. Ho dehydrated the hemihydrate by heating it in a vacuun over $\mathrm{P}_{2} \mathrm{O}_{5}$ and took special precautions to prevent rehydration, which he claimed took place in Jung"s experiment. He found the stronger lines for the two materials to coincide, but most of the veak linos showed an ontirely different spacing. In sevoral cases lines present for one material were absent for the other. He concIuded that the struetures were different but that the most densely fllled planes had the same spacing. He stated that the spacing changed continuously with loss of water. Indicating that the vater in hemihyrate is zoolitically bound.

Onorato (27) was unablo to find ony apprectable difference in the affraction patterns of soluble enhydrite and heminydrite, and concluded that the structures are identical (monocinic, 8 molecules per unit cell). Gall1te17i (14) reported that soluble anhydrito prepared through dehydration of hemihydrate has essentially, with exception of a small lattice shrinkage, the same strueture as hemihydrate. The hemihyarate 1 monoclinic, $a_{0}=11.94$, $b_{0}=6.83, c_{0}=12.76$ (12 molecules per unit cell). He used 
the rotating crystal method to find $a: b: c=1.7438: 1: 1.8515$ and $\beta=9036^{\circ}$.

Caspari (9) found the hemihydrato to be hexagonal $\left(a_{0}=6.76, c_{0}=6.24\right)$ and declared the crystels give up vater to vithin $0.1 \%$ or loss of dehydration without losing form or transparency.

Gaubert (15), in an optical investigation, found evidence that the hemihydrate is hexagonal and not zeolitic. The most recent paper on the homihydrate probIen is that of Balarev and Koluscheva (4). Isotherns for both dehydration and rehyaration were found to bo zeolitic and to differ by about I m. Hg. Balarew concluded that the hemihydrate is zeolitic and that van't Hor's solublo anhydrite is different from the dehydrated hemihydrate of Linck and Jung. Soluble anhydrite can be prepared in HIrOgof $50^{\circ}$ and $4.0 \mathrm{rm}$. equeous pressure, while the vapor pressure of dehydrated hemihyrrate is about I mm. Balarev says thet the dehydration of eypsum results in a mixture of soluble anhydrito and dehycrated hemihydrate. On rohydration the soluble anhydrite goes to gypsum and the dehydrated hemihydrate to hemihydrate. This misture is plaster of Paris. Its composition was provod analytically and microscopicaliy. 
The preceding revien of the ilterature demonstrates that the nechanism of dehyouration of calcium surfate hamihydrate and even its existence is open to question. Important work on this question has been cerried out by dehydration and $x-x$ ay diffraction methods. Iinck and Jung (25), Gibson and HoIt (17), Balarery (4), and Kraus (22) have reported that plastor or Paris loses its water continuously after the manner of zeolites. On the other hand, Balarev at one time (I) cloimed that isobaric dehydration shored the material to be a typical hydrate, and later (3) stated that the water is hold in a nev manner"half hydratic and half zeolitic". Parsons (28) Pailed to find any evidence of a hemihydrete on dehydration of gypsum and concluded that plaster of Paris is not a compound. HowevGr, the consensus of opinion seems to be that the so-called homihydrate is a compound of the zeolitic type. X-ray invostigations, thile apparontly disagreeing in actual oxperimental results, have in all cases been interproted as indicating that calcium sulfate hemihydrate is zeolitic in nature. Thus Jung (21). Ransdell and Partridgo (31), and Caspari (9) roported that the $x$-ray diffraction-patterns of the hemihydrate and of 1 ts dohydration product, dehydrated hemihydrate are identical. It shoula be pointed out thet van't Hors, Hinrichsen, and Woigert (34) prepared a soluble fom of anhydrous calciun sulfate by treating gypsum with nitric acla containing 2.38 mols vater per mol nitric acid above $50^{\circ} \mathrm{C}$. This materiol was celled "soluble anhydrite" to distinguish it fran ordinary anhydrite, and this name has been generally used for the dehydration product of henihydrate. Balarew (3), howover, 
Onorato (27) and Gallitell1 (14) concludod that the structuros of the two meterials are ldentical but recognized small afferences in the diffraction patterms. Feitnecht (12) found depinite differences in the powder photographs of the two materials when special care was taken to provent rehydration, but interproted his results to indicato that the material is zeoiltic.

The purpose of the present investigation is to check the existence of a hemihydrate of calcium sulfate and to study the mechantsm of 1ts dehydration. Exporiments carrled out by x-ray diffraction and vapor pressure methods show that calcirm sulfate homihydrato is a derinite chemicel compound that decornoses stepwise in typlcal hydrate fasinion to give another conpound, dehydrated henibyarate, which hos an x-ray diffrastion pattem distinct Pron those of the howinydrate and anhydrite.

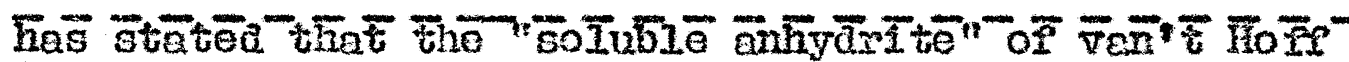
is different from the material obtained by dehydration of henihydrate. Both Balarew (3) and Partridge (31) prePer to apply the term dehydrated hemihydrate to tho dehydration product, and this torminology will bo adhored to in this paper. 
Drperimental

Isoberic Delnearation. The gypsum used for these experiments was trensparent solenite which vas ground in an agate mortar. Isobaric dehydration of this material was carsted out in an apparatus that had boon previousiy used for this puxpose (55). Somples wero kept in woighing bottles in an electric oven. The temperature was maintained constant within $\pm 1^{\circ}$ for short pertods of timo and to vithin $\pm 2^{\circ}$ for longer poriods. A constant aquoous vapor prossure of $23.5 \mathrm{~mm}$. Was maintained by passing air through vater at $25^{\circ} \mathrm{C}$. This alr was then proheated by passing it through a 15 foot glass coil in the oven. AII samples used meighed approxinately 0.2 gran.

A completo dohydration-lehydration isobar was Iun for one sorple. The rosults aro giten in Table 1 and Figure 1. Dehydration of four additional semples Was studied for the heralhydrate poztion of the curve. The results of this investigation are given in Tab2e 2 and Figure 2. The points on the curve represent the average deviation or less than $0.01 \mathrm{~mol}$. The samples vere held at the various temperatures for extranely long periods of time and weighed at intervals until oquilibrium nes Ienchod. In some cases over 500 hours nese allowod to insure equilibritu. 
Table 1

Isobaric Dohydration-Rehydration Data

Dehydration

\begin{tabular}{|c|c|}
\hline Temperature & $\begin{array}{l}\text { Composition } \\
\text { Hols } \mathrm{H}_{2} \mathrm{O} / \mathrm{HOI} \mathrm{CaSO}_{4}\end{array}$ \\
\hline 40 & 2.00 \\
\hline 49 & 1.98 \\
\hline 55 & 1.90 \\
\hline 60 & 1.58 \\
\hline 75 & 0.52 \\
\hline 80 & 0.52 \\
\hline 89 & 0.51 \\
\hline 105 & 0.04 \\
\hline 115 & 0.03 \\
\hline 140 & 0.02 \\
\hline
\end{tabular}

Rohydration

$\underset{0}{T}{ }_{0}$

105

100

95

91

85

80
Composition Inols $\mathrm{H}_{2} \mathrm{O} / \mathrm{MHO} \mathrm{CaSO}_{4}$

0.03

0.04

0.47

0.47

0.18

0.48 
Figure 1

Dehydration-hoingdration Isovar 


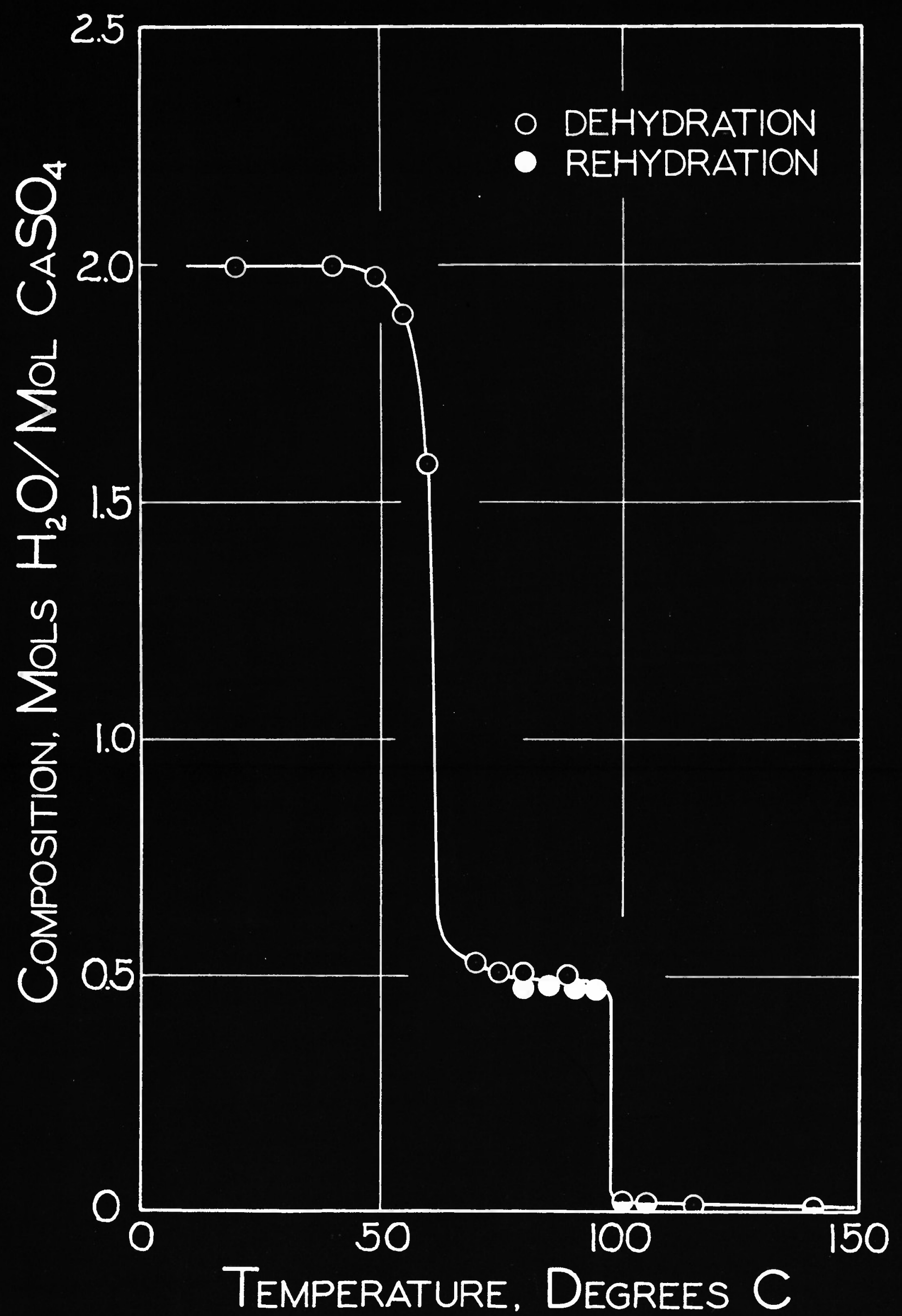




\section{Table 2}

\section{Isobaric Dehydration Dato}

\begin{tabular}{|c|c|c|c|c|}
\hline \multirow[t]{2}{*}{ Temperature } & & \multicolumn{3}{|c|}{$\begin{array}{l}\text { Composition } \\
\text { Mols H2O/Hol } \mathrm{CaSO}_{4}\end{array}$} \\
\hline & 1 & 2 & 3 & 4 \\
\hline 25 & 2.00 & 1.98 & 2.00 & 1.99 \\
\hline 70 & 0.52 & 0.54 & 0.55 & 0.54 \\
\hline 75 & 0.52 & 0.55 & 0.55 & 0.54 \\
\hline 80 & 0.52 & 0.52 & 0.53 & 0.52 \\
\hline 89 & 0.52 & 0.52 & 0.53 & 0.53 \\
\hline 95 & 0.51 & 0.52 & 0.52 & 0.52 \\
\hline 100 & 0.08 & 0.08 & 0.10 & 0.10 \\
\hline 105 & 0.05 & 0.05 & 0.07 & 0.07 \\
\hline 163 & 0.01 & 0.02 & & \\
\hline 185 & 0.01 & 0.02 & & \\
\hline 220 & 0.01 & 0.02 & & \\
\hline
\end{tabular}




\section{Bisure Dohydration Isobar of Calciura Sulrato Heminydrato Wech point represents the everage value tor four separato samples)}




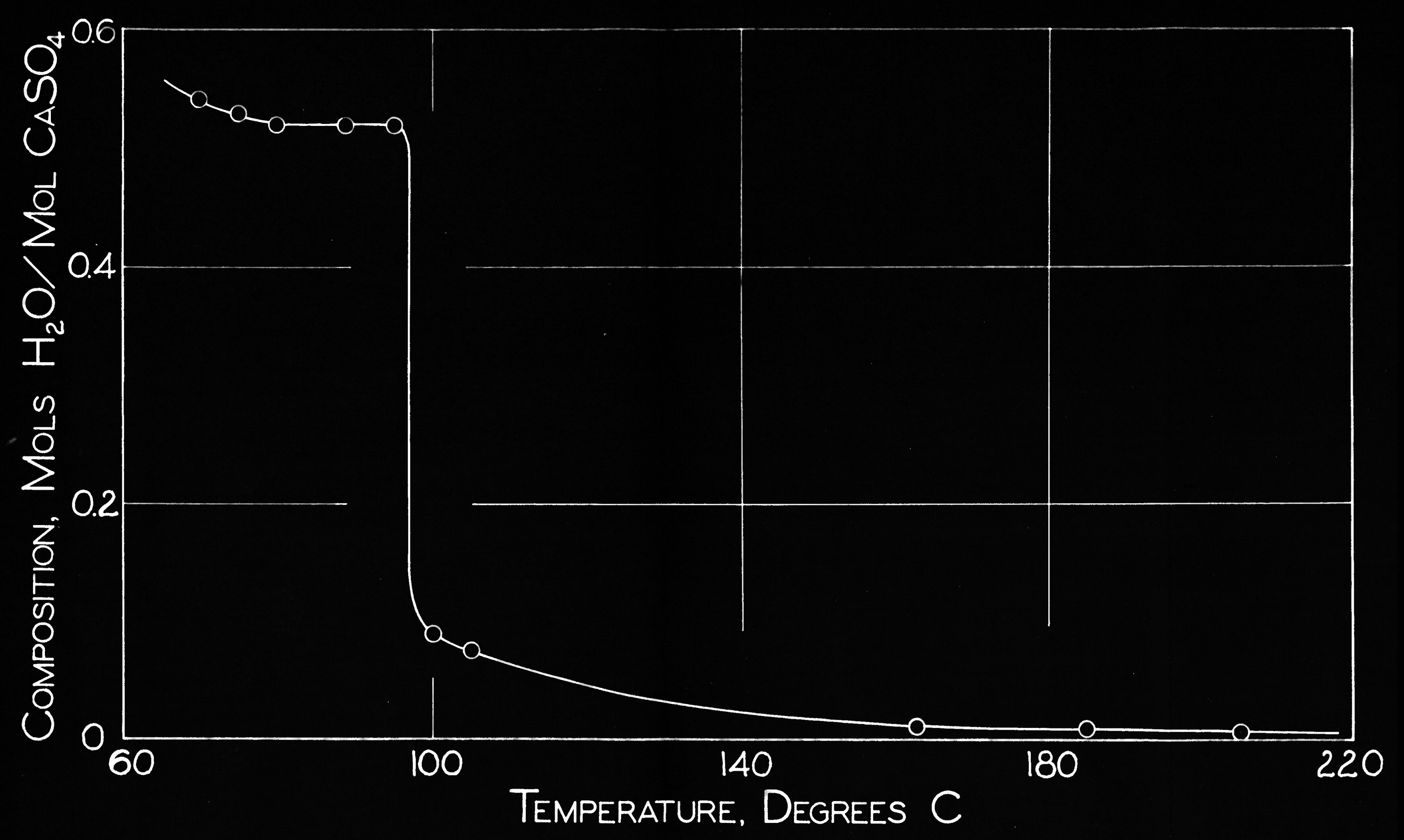




\section{X-tay Ditenotion homination. A proluminary}

study of the I-rey difrection petterns of (a) $\mathrm{CoSO}_{2} \cdot \mathrm{RH}_{\mathrm{i}} \mathrm{O}$, solenite; (b) hemingarate preperec by hoating (a) to $95^{\circ}$ at a vapor pressure of $23.6 \mathrm{~mm} \cdot$; () dehydrated heninydrato prepared by heating (a) at $145^{\circ}$ in a vacuum; and (d) enhy-. drite prepared by heating $(2)$ at over $400^{\circ}$ was made by means of a General inoctric $x$-ray affraction outeit with $\mathbb{K}_{\alpha}$ lfo radiation. Wins were stenderdized by means of pure sodiun chloxide. As the dehydrated matexial is highly hygroscopic (5), (20), it vas found necessary to oxercise great care in obtaining samples. The semplo tubes wore filled with dehyorated hominydrate in the oven before the vacum dehydration. heter 24 hours heating in a vacum, dry air was allomed to onter through a U-tubo Pliled with magnesium perchlorate and the sample tubes sealed off lmmeriately insido the oven. The seals wero exanined mieroscopically for imperitections. The results of this preliminary investigation are given in Figure 3. From the diagran it is apparent that there are rour distinct crystal forms of calcium sulfate. Although the henihydrate and dehydrated henihydrate patterns aro sinilar, they are not identical. Samples were also propared by heating gypsun 24 hours in a vacum at $124^{\circ}$. $159^{\circ}, 180^{\circ}$, and $219^{\circ}$. The pattoms obtainod wore icienticol with that for dekydrated hominydrate in all ceses, shoving that the semples vero free from anhydrtte and undecomposed homihydrite. Anelysis of naterial dehydrated 


\section{isgare 3}

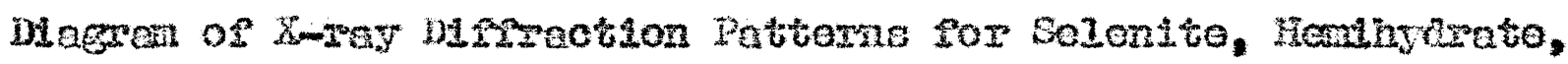
Dehydratod Henihydrate, and Anhydrite (G.I. apparatus, $\mathrm{k}_{\alpha}$ ho radiation) 


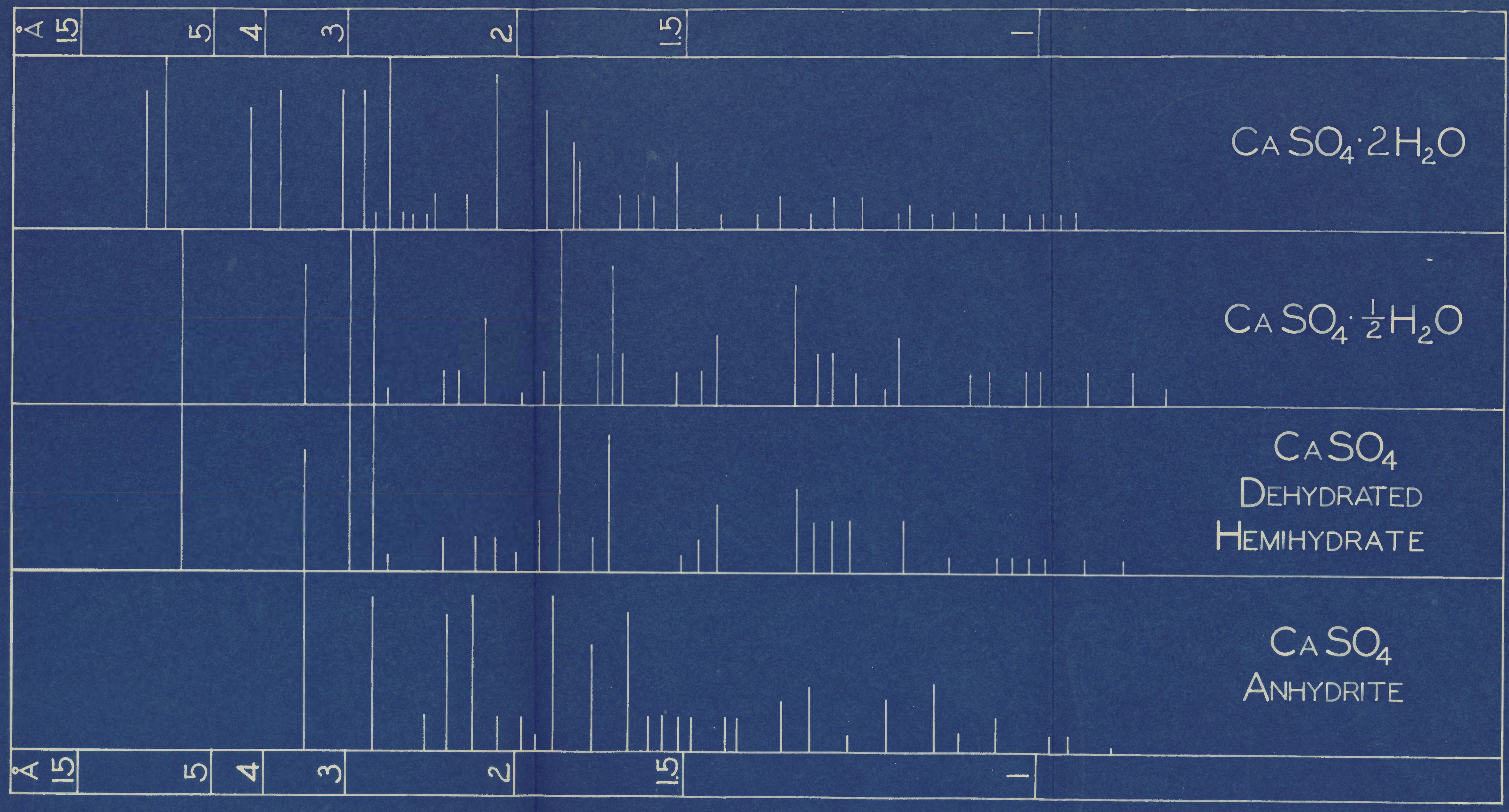


simultaneousiy with these sanples showed that they contained \pm 0.01 mols water per nol calcim surpate. The tube containing the 15 A $^{\circ}$ dehydratod henihycrate was openod and the material alloned to rohydroto oror night in the atmosphere. The dffrection pattern of this rehydrated material corrosponded to that of henihydrate. Rehydration of scimples dehydrated at $159^{\circ}$ and $219^{\circ}$ rosulted in ccmpositions of 0.65 and 0.60 mols $\mathrm{H}_{6} \mathrm{O}$ per nol CoSO $\mathrm{nospec-}$ tivaly.

A more exact detomination of the difrerencos botwon the z-ray aifraction digstans for the henthydrate and dehydrated homihgorato was curried out by moans of a Soemarin crystal analysis unit fith $\mathrm{Cu}_{\mathrm{K}} \mathrm{K}_{\alpha}$ radiation filtered through nickel roll. A precision Debve-scherrer camera bith a daneter or 125.6 mon. Wes useti. Long exposures weice required because of the lor symotry of the matertal. the small primary particle sizo, the laxge sizo aperture or the canera. and tho necessity por obtaining a lergo numer of 1ines. The exposuro time was 30 to 35 hours at $60 \mathrm{~m}$. a. ma $40 \mathrm{k}$. $\nabla$. The sanples wore placed in Lindenann glass fubes and cxtreme care used to prevent rehydration as described ebove. Pure nickel oxd co for use as a standard was Drepared by recrystallizing nlchel nitrate throe vines and igniting in a curront of nitrogon. The lattice constant of this nichol oxide (8) was takon as $4.1684 \AA$ in calculating the cansra radus. This value of the radius 
vas checked by redetemining the lattice constants of copper and rijkel oxide on separate films. These velues were obtained by the method of Bradiey and Jay (6), but were not corrected for film shrinkage.

Mickol oxide was also used in order to comect the calcim sulfate pattems for possiblo errors due to PIIn shrinkage, eccentricity of sample, and absorption in tine semple. This material wes mizod with the samplos In a ratio of about 1 part nickel oxtde to 12 perts calclum sulpate. The volues of sino for the varicus reflections of niekel oxtde pere detemined frat the observed spacings on the Plim. These values were then compared to those calculated essuming $a_{0}=4.1684$. A curvo obtained by plotting corrections against $\sin \theta$ mes used to detexnine the corrections for the various replections irea calciun sulfate. The results are givon in chart form in Flgure 4, while sme of the negatives are reproduced in Figure 5. The corsected data for purpose of comperison is given in Table 3 . The intorplanas spacings in Angstroms are denoted by d binl and the ostimated relative intensities by $I$. The pattern cor a samplo obtained at $164^{\circ}$ in a vapor pressure of $23 \mathrm{~mm}$. vas identical with that obtained by dohydreting the henihydrate 24 hours in a vacum at $145^{\circ}$. 
Figure 4

Diagran of X-ray Diffraction Pattoms for Heminydrate and Dehydrated Heminyarate (Seemann apparatus, $\mathrm{K}_{\alpha} \mathrm{Cu}$ radiation) 

F1 gure 5

X-ray Diferaction Pattems of Hemihydrate and De iydrated Hemihydrete

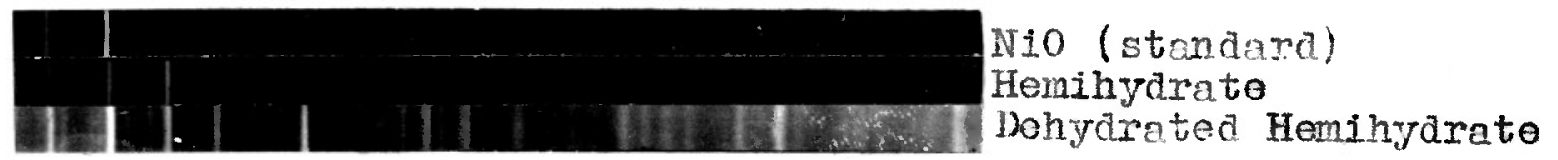


Table 5

Xrmay DLffraction Data

Eeminyarate

$\mathrm{CaSO}_{4} \mathrm{O} .5 \mathrm{H}_{2} \mathrm{O}$
Dehydrated Hemihydrate $\mathrm{CaSO}_{4}$

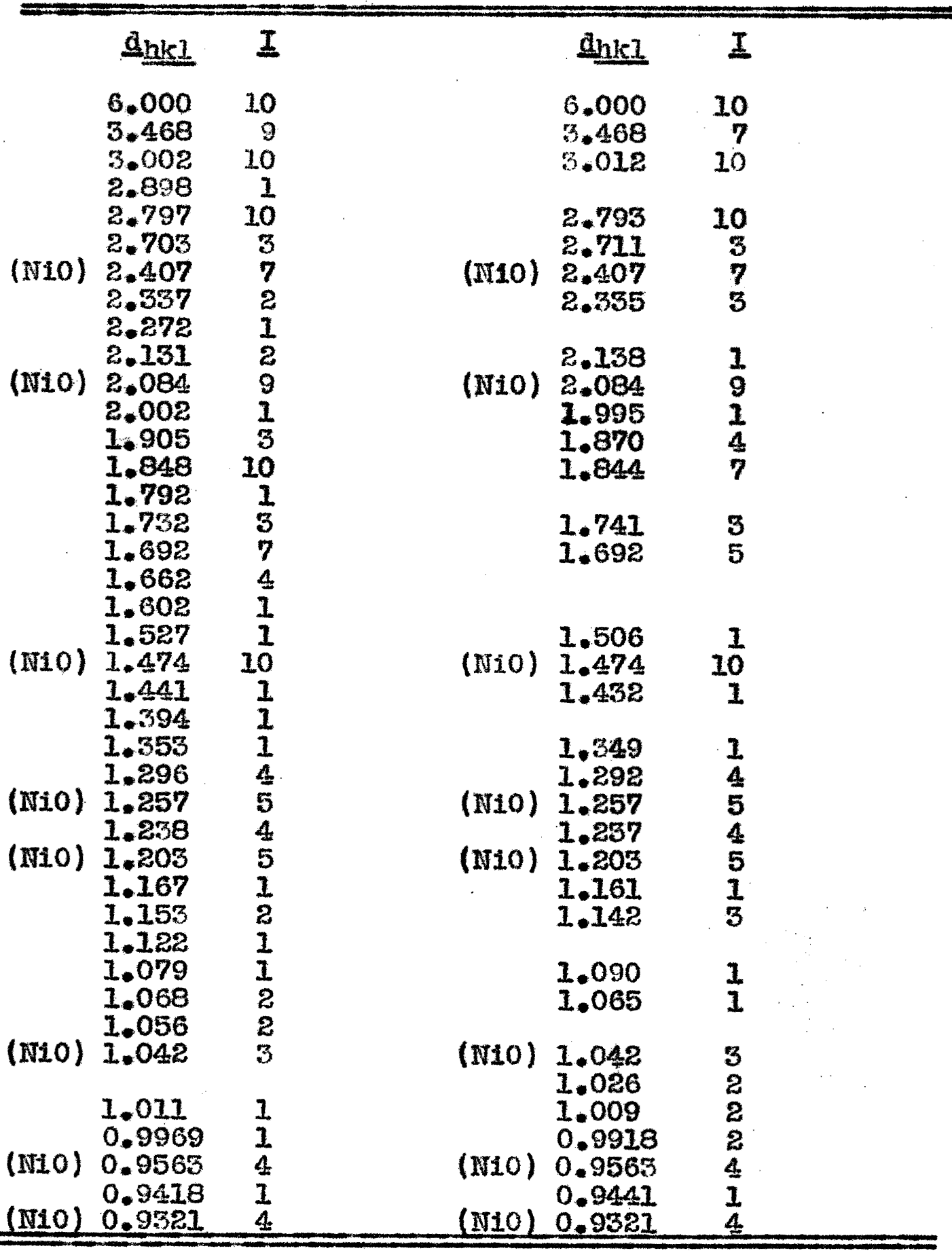




\section{Discussion}

Isobaric dehydration of grosum rasults pirst in the fometion of the henihydrate, which adsorbs a sme11. amount of vater. Upon further hoating, the homihydrate decoraposes stepwise into the highly hydrous dehydrated hemihydrate. This material which is a vory strong dessicant (5), (20) does not 10 se all of its vater until heated at tomperatures much groator than the heminydrato deconposition temperature. The dehydration isobars for henihydrate, both on dehydration and Iehydration, are clearly imical of hydratic docomposition of a hydrous material into a material that adsorbs water, and show no Indication of a continuous, zeolitic loss of water. These resulis are in agreernent with the isobar of Iinck and Jung (25) and that rirst obtained by Balaren (1). the isotherms of Balaren (4) seon to indicate the hemihyarate loses nost of its water at the swe vapor pressure although it shows an apparent gradual decrease in vapor pressure with the loss of approxinately the last 0.1 mol. It appoars 11koly that this rinal continuous part of the isotherm is due to the loss or adsortied treter. The conflicting results obtained by fincle and Jung and others mast bo attributer to the railuze to obtain equilibrium.

X-ray dirfraction studies shov that there are Pour separate erystel forne of calciun sulfate: expsun, hemihydrate, dehydrated homihyarate, and anhydrite. 
The porder diffraction pottern for dehydrated heminydrate, while very sinilar to that of heminydrate, has distinct characteristic alferences. The close agreenent botwoen the principal rerlections of the two materials shows that the type of lattice and size of the untt cell are stmilar. However, the pronouncol changes in the heminyorate pattern on dehydration indicate that the weter molecwles occupy derinite fixed positions in the lattice. The heninydrate of calcium sulfate, therefore, cannot be classed anong the compounds of zeolitic type, which show no chenge in crystal structure on dehydration. Jung (21), Ramsde11 and Partridge (31), ond. Caspari (9) reported that powder photographs of the two materials are the some, while Onorato (27), and Gallitelli (14) stated that the structures aro idontical. but recognize small differencos in tire pattorns. It appoars that the latter investigators ald not realize the signiricance of the snall differenoss involved. This case is not unique; Q. S., Dradloy and Roussin (7) havo reported the existence of a range of alwino-silicate compounds, the mullites, Which likeviso show small, but distinct, differences in z-ray powder photographs. The fallure of other investigators to recognize the chonge in the heruihydrate pattern on dehydration was probably due to tho use of smell size cameros, use of molybonum radiation in same cases, the follure to use a reference material to stenderdize films, and the failure to prevent rehydration of dehydrated material. 
However, using a large camera, standardizing material, copper radietion, end taking cere to prevent relydration, the differences obtained aro unquestioneble. "Ihese ditPerences agree qualitatively with those of Feitnecht, but exact comparison is impossible because this investigator published his results only in rough chart rorn. 


\section{Summary}

1. Contrary to the results or Balarew, Linck and Jung, Givson and Holt, and others, celcium sulfato hemihydrate on dehytration does not lose its vater continuously after the mamer of zeolites. Careful isoberic dehydration results in a univariant step curve or the typical hydrate type.

2. Contrery to the conclusions of Jung, Ransäil and Partridge, Caspari, Onorato and Gallitolli, the structure of dehydrated hamihydrate is not identical with that of hemingirate as would be expectod for a zeolitic type compound. Whilo the structures are analogous, $x$-ray difpraction diagrans obtained by precision mothods show distinct differences betwoen the two naterials. The mater molocules form an essontial part of the lattice and their removal causes a small, but definite rearrangement of the wit cell. These results are In accord with those obtained by vapor pressure nethods which show that calcium sulfate hemihydrate is a definite chemical corpolmd of the ordinary hydrate type. 


\section{BIBI.IOGRAPIIY}

(1) Balarew: Z. anorg. allgen. Char., 156, 258 (1926)

(2) Balarov: IoLd., 263, 187 (2927)

(3) Balarem: Kolloia $4 ., 48,65$ (1929)

(4) Balarev and Koluscheve: Inid., 20, 288 (1935)

(5) Bover: Bur. Standards J. Reseerch, 12, 24.1. (19:4)

(6) Bradley end Jay: Proc. Phys. Soc., 44, 503 (1032); 45, 507 (1935)

(7) Bradley and Roussin: Trans. Coren. Soc., 31, $42 \%$ (1952)

(8) Caims and ott: J. Am. Chem. Soc., 55, 527 (1955)

(9) Caspari: Nature, 1.3, 048 (1934)

(10) Chassevert: Ann. Chim., 6, 2M (1926)

(11) vavis: J. Soc. Chem. Ind., 26, 727 (1.907)

(12) Foltnecht: Helv. Chim. Acte, 14, 85 (1951)

(13) Fill: Diss. (Berin, 1251)

(13) Gallitella: Lomodico min., $4,1,132$ (1982)

(15) Gaubert: BuIl. soc. franc. mineral, 252 (1054)

(16) Gavderroy: Compt, rend., $158,2006(1914) ; 159$

(17) Gibson and Ifolt: J. Chem. Soc., 638 (1933)

(18) Gasenapp: Tonind $z_{*}, 32,148$ (1908)

(19) Grengg: 2. anomg. 217gem. Chem,, 30, 32? (1914)

(20) Hesmond and withrow: Ind. Ing. Cham., 25, 653 (1935)

(21) Jung: Z. anorg. angem. Chers., 142, 43 (1925)

(22) Kraus and Jorns: Tonind $\%$. 54, 1467 (1950)

(23) Liocroju: Compt. rend., 126,:60, 555 (1898)

(24) Lo Chatelion: Compt. rend., 96, 1668 (1883)

(25) Linak and Jung: Z. anoIg, allgem. Chem., 156, 258 (1926)

(26) Milion: Ann. Chim. Hhys., 19, 222 (1847) 
(27) Onorato: Foriodico Min, 3, 128 (1932)

(28) Parsons: Unit. Toronto Studies. Gool. Sor.. No. $24, p=24$ (1927)

(29) Partriage and whits: J. Am. Cnom. Soc. 51, 860 (1929)

(50) Potilitzin: J. Huss. Phys. Chem. Ges., 36, 170, 221 (1894); 27, 265 (1895)

Borichte, 27, 613 (1894); Chem. Zentr.. $189 \mathrm{~g}, 515,609$.

(31) Hamsde11 and Partzidge: An. Minoral., 14, 59 (1929)

(52) Shulrsulte Kozu and hasuda: Sctence Reptis. Tohwio Imp. Univ. Ser. III, 8 (1926)

(65) stumper: Z, anorg. al1gem. Chen., 162, 127 (1927)

(34) Van't Hops: Z. Phys, Chome, 45, 257 (1908)

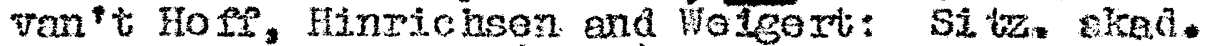
VIss. 570 (1901)

vanti Hose and gext: Intd, 240 (1900)

van't HofP and Armstrong: Ibid., 563 (1900)

Tan't HoPf and Just: Thid $; 240(3003)$

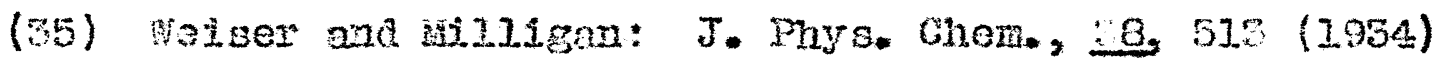

